Article

\title{
Experimental Study and Mathematical Modeling of Convective Thin-Layer Drying of Apple Slices
}

\author{
Mohammad Jafar Royen ${ }^{1,2}$, Abdul Wasim Noori ${ }^{1,2}$ and Juma Haydary ${ }^{1, *}$ (I) \\ 1 Department of Chemical and Biochemical Engineering, Slovak University of Technology in Bratislava, \\ 81237 Bratislava, Slovakia; Jafar.royen@kpu.edu.af (M.J.R.); awnoori@kpu.edu.af (A.W.N.) \\ 2 Faculty of Chemical Technology, Kabul Polytechnic University, Kart-e Mamoorin, Kabul 1001, Afghanistan \\ * Correspondence: juma.haydary@stuba.sk; Tel.: +421-259-325-252
}

Received: 1 October 2020; Accepted: 24 November 2020; Published: 27 November 2020

\begin{abstract}
This work represents an experimental study and mathematical modeling of convective apple slice drying. The influence of multiple process parameters such as temperature, air humidity, air velocity and slice thickness on process kinetics, product water activity and parameters of empirical models has been investigated. Drying characteristics of apple slices were monitored at temperatures of 40,45 and $50^{\circ} \mathrm{C}$, air velocities of $0.6,0.85$ and $1.1 \mathrm{~m} / \mathrm{s}$., slice thicknesses of $4,6,8,10$ and $12 \mathrm{~mm}$, and in relative air humidity ranges of $25-28,35-38$ and $40-45 \%$. During the process, samples were dried from an initial moisture content of $86.7 \%$ to that of $20 \%$ (w.b), corresponding to product water activity of $0.45 \pm 0.05$. By increasing the temperature from 40 to $50{ }^{\circ} \mathrm{C}$, the time for reaching the required product water activity decreased by about $300 \mathrm{~min}$. Sample thickness is the most significant parameter; by increasing the slice thickness from 4 to $12 \mathrm{~mm}$, the time required to achieve the required water activity increased by more than $500 \mathrm{~min}$. For all experimental runs, parameters of five different thin-layer empirical models were estimated. A thin-layer model sensible to process conditions such as temperature, air velocity, layer thickness and air relative humidity was developed and statistically analyzed.
\end{abstract}

Keywords: convective drying; thin-layer models; apple; water activity; drying kinetics; diffusion

\section{Introduction}

Agricultural products such as fruits and vegetables are considered perishable foods because of their high moisture content [1]. Preservation for off seasonal time and prevention from microbial spoilage and enzymatic reactions can be accomplished by removing free water from the foods [2]. Drying is a well-known method of free water removal and preservation, extending shelf-life, and decreasing transportation weight and space requirements for storage [3-6]. Drying is, however, an energy-intensive process. Convective drying usually requires hot air circulation; however, high temperature and long times required in hot air-drying adversely affect the texture, flavor, and color of products $[7,8]$. Many parameters affect the drying process; temperature, air relative humidity, air velocity, and particle sizes of dried material can significantly influence the required drying time, cost as well as product quality.

Apples (Malus domestica) are a widely cultivated fruit consumed either fresh or as juices, jam or dried products. They are a good source of dietary fibers, pectin, potassium, vitamin C and vitamin A and phenolic compounds [9]. Dried apples can be used in snack food, as a weak seasoning and as a complimentary ingredient of special diets [10].

Drying of apples was the subject of study in a number of researches in recent years [11,12]. Several works deal with effect of process parameters on the drying rate and quality of the product. Lewicki and Jakubczyk [13] dried apple slices with irradiation at temperatures of 50, 60, 70 and $80^{\circ} \mathrm{C}$; the effect of hot air temperature on the rate of drying at $80^{\circ} \mathrm{C}$ is twice that observed at $50^{\circ} \mathrm{C}$. Togrul [14] 
studied infrared drying of fresh apples by simple modeling in the temperature range of $50-80{ }^{\circ} \mathrm{C}$; drying time decreased by $80 \mathrm{~min}$ when the temperature was increased from 50 to $80{ }^{\circ} \mathrm{C}$; also the drying rate was almost doubled. Wang and Chao [15] dried apple slices by irradiation at three temperatures: 50,60 and $75^{\circ} \mathrm{C}$; at the same dehydration time, the higher the air temperature for constant irradiation, the more water was lost. Fresh apples were conventionally dried by Velic et al. [16] at air velocities of $0.64,1.00,1.50,2.00,2.50$ and $2.75 \mathrm{~m} / \mathrm{s}$ and a drying temperature of $60^{\circ} \mathrm{C}$ using rectangular-shaped $(20 \times 20 \times 5 \mathrm{~mm})$ apple slices; they reached a moisture content of $20 \%$ (wet base), then the dried samples were rehydrated with about $72 \%$ of the water that was removed by the drying process. Vega-Galvez et al. [17] studied the effect of temperature and air velocity on the drying kinetics and product quality; apples were dried at different temperatures and air velocity $\left(40,60\right.$ and $80{ }^{\circ} \mathrm{C} ; 0.5$, 1.0 and $1.5 \mathrm{~m} / \mathrm{s}$ ). The highest drying rate constant of $15.30 \times 10^{-9} \mathrm{~m}^{2} / \mathrm{s}$ was obtained at maximum experimental temperature and air velocity $\left(80^{\circ} \mathrm{C}\right.$ and $\left.1.5 \mathrm{~m} / \mathrm{s}\right)$, while the lowest drying rate constant of $3.22 \times 10^{-9} \mathrm{~m}^{2} / \mathrm{s}$ was obtained at $40^{\circ} \mathrm{C}$ and $0.5 \mathrm{~m} / \mathrm{s}$. Color attributes of apples change during their hot air drying, which was confirmed by Nadian et al. [18] when drying apple slices of $4 \mathrm{~mm}$ thickness at $60{ }^{\circ} \mathrm{C}$ and at a rate of $1.5 \mathrm{~m} / \mathrm{s}$.

Several empirical mathematical models were employed in many literature sources for modeling fruit drying. However, empirical-based models such as those of Lewis (Newton) [19], the Page model [20], the modified Page model [21], that of Henderson and Pabis [22], the logarithmic model, and the two-term model [23], are the most frequently used to model drying of different agricultural products.

Drying is an energy extensive process. The use of renewable energy sources, particularly solar energy, can significantly affect the economy of the process and reduce the carbon footprint. However, traditional open sun drying leads to the deterioration of quality parameters and contamination of the product. An alternative to open sun drying is active indirect cabinet solar drying [5,24]. Drying performance of a solar drying system is highly dependent on the climate conditions of the given geographical location. Geographical locations with dry climate and high altitude such as Afghanistan, where this research was done, provide ideal conditions for solar drying application.

Although convective drying of fruit including apple slices has been studied by numerous researches, a complete investigation of the influence of multiple process parameters, such as temperature, air humidity, air flow velocity and slice thickness, on process kinetics, parameters of empirical models, and particularly product water activity has not been published to our knowledge. In addition, available experimental data were typically obtained at conditions different than those typical for geographical locations with dry climate and high altitude.

This work aims to investigate convective thin-layer drying of apple slices at temperatures ranging from 40 to $50{ }^{\circ} \mathrm{C}$, ambient air relative humidity from $25 \%$ to $45 \%$, air velocity from 0.6 to $1.1 \mathrm{~m} / \mathrm{s}$, slice thickness from 4 to $12 \mathrm{~mm}$ at an average ambient pressure of $82 \mathrm{kPa}$, typical of geographical locations with an altitude of 1800 to $2000 \mathrm{~m}$ above sea level. The selected air velocities and temperatures correspond with values achievable in forced convective solar drying units [5], since the results are aimed to be used in the design of convective solar drying units. The effect of process parameters on the effective diffusion coefficient and kinetic parameters of different empirical models was observed in this work. Optimal drying time under each set of conditions was estimated by observing the change in water activity of the dried product during the process.

\section{Materials and Methods}

\subsection{Sample Preparation}

Red apples (Malus domestica) used in the study originated from the Maidan-Wardak province of Afghanistan and were obtained from a local supermarket in Kabul; they were then stored at $+4{ }^{\circ} \mathrm{C}$. Fresh red apples with diameters ranging from 60 to $80 \mathrm{~mm}$ were selected, washed with distilled water and cut horizontally along their axis (each piece was parallel to the main axis of the apple) with a 
manual cuter into cylindrical $6 \pm 0.1 \mathrm{~mm}$ thick slices (Figure 1a); to analyze the effect of slice thickness, apples were cut into 4, 8, 10 and $12 \pm 0.1 \mathrm{~mm}$ thick slices (Figure 1b).

\section{a)}

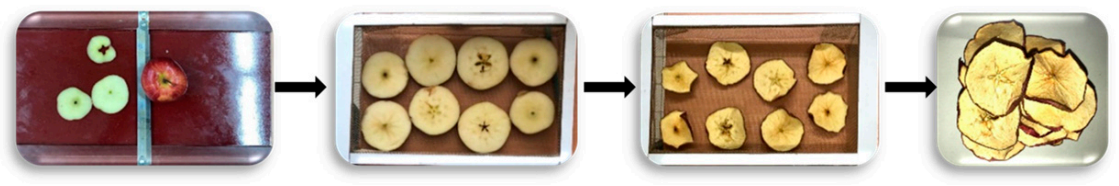

b)

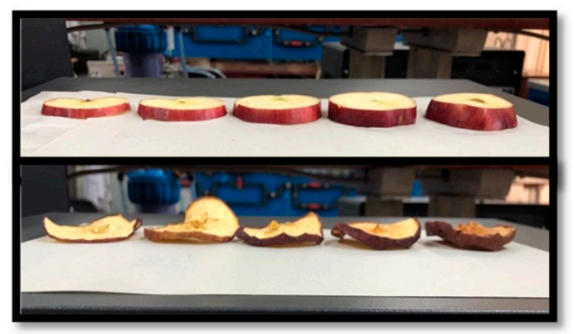

Figure 1. Sample preparation: (a) a sample batch with $6 \mathrm{~mm}$ apple slices, and (b) slices with different thicknesses.

Each batch comprised $300 \pm 2 \mathrm{~g}$ of apples. The average initial moisture content of the apples was $86.7 \%$ (wet basis) which was determined in a laboratory moisture analyzer (VWR MBT160 moisture analyzer, number 611-2318, VWR International, Italy) equipped with an analytical moisture balance (capacity of 0.001-160 g), a heater power supply and stainless pan protection with a ventilation stopper.

\subsection{Experimental Procedure}

Food and agriculture products can be dried by several methods, such as solar, freeze, infrared, microwave and convective drying. Convective drying is the most popular among these methods for moisture removal in a variety of industrial applications [25]. Therefore, a laboratory batch convective tray dryer shown in Figure 2 was used to dry apple slices. The unit is made of a stainless steel tunnel with the dimensions of $2000 \times 450 \times 400 \mathrm{~mm}$ (length, height and width, respectively), with aluminum on the outside and expanded polystyrene plates between the metal layers to minimize the heat transfer through the chamber walls. The unit was also equipped with heating elements $(3 \mathrm{~kW})$, an axial fan with angular frequency of 0 to $2500 \mathrm{rpm}$, three drying trays, a control system, a load cell-force sensor (range: $0-5 \mathrm{~kg}$ ) with continuous mass balance, an air flow sensor (0-150 L/s), as well as temperature and pressure sensors. The axial-flow fan was located at the entrance of the drying tunnel to feed air into the tunnel. The air flow rate was set at the beginning of the process. Heating elements, which were placed next to the fan, heated the air and controlled the temperature. The unit has three strategically located hygrometers to ensure optimum humidity and temperature required for the system. Hygrometers consist of two temperature sensors (wet bulb) wrapped in an absorbing cover and the other (dry bulb) which is located directly in the tunnel. Sliced apples were placed on perforated trays in the tunnel of the load cell; the balance and load cell were connected to the control interface box and data acquisition software with balance calibration option. A more detailed description of the experimental set-up is given in our previous work [26]. 


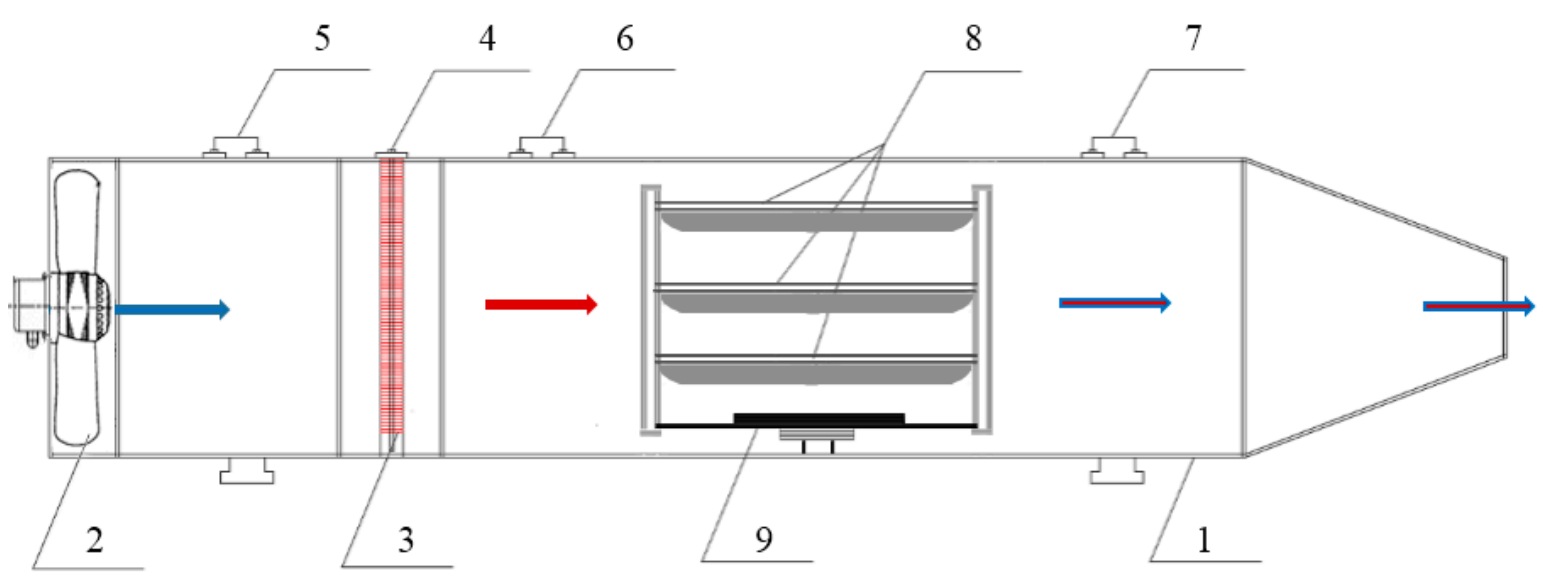

Figure 2. Batch laboratory tray dryer scheme: 1-stainless steel tunnel, 2-axial-flow fan feeding air into the tunnel, 3-heating elements, 4-heating element temperature sensor, 5-temperature sensors before air heating, 6-temperature sensors after air heating, 7-temperature sensors for the air leaving the tunnel, 8-drying trays and 9-balance load cell-force.

The dryer was first run without the samples for about 10 to $15 \mathrm{~min}$ to set the desired conditions before each batch drying, samples, after being sliced, were placed on three trays and placed inside the chamber above the balance. The balance was set to record the sample mass every two minutes.

During the process, apple slices were dried starting from the initial moisture content of $86.7 \%$ to the final moisture content of $20 \%$ (w.b). The sample mass was recorded every two minutes. The experiments were carried out under average ambient temperatures of $15-20^{\circ} \mathrm{C}$, pressure of $82 \mathrm{kPa}$ and an air average relative humidity of $25-45 \%$. Drying characteristics of the apple slices were studied at three temperature levels: 40,45 and $50{ }^{\circ} \mathrm{C} \pm 1$ before the drying chamber, which corresponded to 50 , 60 and $70{ }^{\circ} \mathrm{C} \pm 1$ controlled close to the heater, and at three air velocities: $0.6,0.85$ and $1.1 \mathrm{~m} / \mathrm{s}$, for each temperature level. In these measurements, the apple slice thickness was $6 \mathrm{~mm}$. The experimental runs at 40,45 and $50{ }^{\circ} \mathrm{C}$ for air velocities of $0.85 \mathrm{~m} / \mathrm{s}$ and $1.1 \mathrm{~m} / \mathrm{s}$ were repeated to measure water activity of the samples. During the last mentioned series of experiments, about $10 \mathrm{~g}$ of dried material was taken from the device each $60 \mathrm{~min}$ to measure water activity.

In the next series of experiments, the effect of slice thickness was investigated. Slices with five different thicknesses: 4, 6, 8, 10 and $12 \mathrm{~mm}$, were subjected to drying at $50{ }^{\circ} \mathrm{C}$, ambient air relative humidity of 35 to $38 \%$ and air velocity of $1.1 \mathrm{~m} / \mathrm{s}$. Finally, experimental runs at three different ranges of ambient air relative humidity: $25-28,35-38$ and $40-45 \%$, were carried out. For these experiments, the chamber temperature was $50{ }^{\circ} \mathrm{C}$ and air velocity was $1.1 \mathrm{~m} / \mathrm{s}$. The air relative humidity was not controlled; the experiments were carried out during different seasons from March to July when different ambient air relative humidities were recorded. In total, 23 runs of drying experiments were carried out, with the duration of each experiment between 5 and $15 \mathrm{~h}$. Table 1 shows a list of experimental runs of this study.

\subsection{Water Activity Measurement}

Water activity of the samples was determined using a laboratory water activity analyzer (LabTouch-aw, Novasina, Switzerland). A sample was taken every $60 \mathrm{~min}$, cut to approximately $5 \times 5 \times 5 \mathrm{~mm}$ and placed in a specific analyzer petri dish. Water activity of the sample at the three temperatures, 40,45 and $50{ }^{\circ} \mathrm{C}$, and air velocities of 0.85 and $1.1 \mathrm{~m} / \mathrm{s}$ for each temperature was determined. 
Table 1. List of experimental runs.

\begin{tabular}{|c|c|c|c|c|}
\hline No. of Run & Temperature $\left({ }^{\circ} \mathrm{C}\right)$ & Air Velocity (m/s) & Thickness (mm) & Air relative Humidity (\%) \\
\hline 1 & 40 & 0.60 & 6 & $40-45$ \\
\hline 2 & 40 & 0.85 & 6 & $40-45$ \\
\hline 3 & 40 & 1.10 & 6 & $40-45$ \\
\hline 4 & 45 & 0.60 & 6 & $40-45$ \\
\hline 5 & 45 & 0.85 & 6 & $40-45$ \\
\hline 6 & 45 & 1.10 & 6 & $40-45$ \\
\hline 7 & 50 & 0.60 & 6 & $40-45$ \\
\hline 8 & 50 & 0.85 & 6 & $40-45$ \\
\hline 9 & 50 & 1.10 & 6 & $40-45$ \\
\hline \multicolumn{5}{|c|}{ Effect of thickness } \\
\hline 10 & 50 & 1.10 & 4 & $35-38$ \\
\hline 11 & 50 & 1.10 & 6 & $35-38$ \\
\hline 12 & 50 & 1.10 & 8 & $35-38$ \\
\hline 13 & 50 & 1.10 & 10 & $35-38$ \\
\hline 14 & 50 & 1.10 & 12 & $35-38$ \\
\hline \multicolumn{5}{|c|}{ Effect of air relative humidity } \\
\hline 15 & 50 & 1.10 & 6 & $25-28$ \\
\hline 16 & 50 & 1.10 & 6 & $35-38$ \\
\hline 17 & 50 & 1.10 & 6 & $40-45$ \\
\hline \multicolumn{5}{|c|}{ Runs for water activity measurement } \\
\hline 18 & 40 & 0.85 & 6 & $40-45$ \\
\hline 19 & 45 & 0.85 & 6 & $40-45$ \\
\hline 20 & 50 & 0.85 & 6 & $40-45$ \\
\hline 21 & 40 & 1.10 & 6 & $40-45$ \\
\hline 22 & 45 & 1.10 & 6 & $40-45$ \\
\hline 23 & 50 & 1.10 & 6 & $40-45$ \\
\hline
\end{tabular}

\subsection{Mathematical Modeling}

Process modeling and optimization of process parameters can significantly reduce the number of experiments required for process design. Drying processes modeling can be formally characterized by two different approaches: physical-based modeling and empirical modeling [27]. Physical models describe the fundamentals of heat and mass transfer during the drying process. This modeling approach requires the knowledge of heat and mass transfer parameters, such as effective diffusion coefficient in both solid and gas phases, thermal conductivity, specific heat capacity, density, etc. and the change caused by material shrinkage during the drying process.

An alternative to physical-based modeling is experimental-based empirical modeling. In literature, many empirical mathematical models applicable for the drying of food and agricultural products can be found; various authors have studied the modeling of the food drying process, e.g., drying of garlic slices [28], tomato slices [29], pepper [30] and apple slices [23].

In this study, parameters of five thin-layer models (Newton, Page, modified Page, logarithmic and Henderson and Pabis) were analyzed under different process conditions. The models are given in Table 2:

Table 2. Thin-layer empirical models considered in this work.

\begin{tabular}{cccc}
\hline No. & Model Name & Model & Reference \\
\hline 1 & Newton (Lewis) & $M R=\operatorname{Exp}(-k t)$ & {$[19,31]$} \\
2 & Page & $M R=\operatorname{Exp}\left(-k t^{n}\right)$ & {$[32,33]$} \\
3 & Modified Page & $M R=\operatorname{Exp}\left[-(k t)^{n}\right]$ & {$[34,35]$} \\
4 & Logarithmic & $M R=a \operatorname{Exp}(-k t)+c$ & {$[23,36]$} \\
5 & Henderson and Pabis & $M R=a \operatorname{Exp}(-k t)$ & {$[37,38]$} \\
\hline
\end{tabular}


$t$ is time, $k$ is the drying rate constant, $a, n$ and $c$ are model coefficients and $M R$ is moisture ratio defined by Equation (1), [25,39,40]

$$
M R=\frac{\left(X_{t}-X_{e q}\right)}{\left(X_{0}-X_{e q}\right)}
$$

where $X_{t}, X_{0}$ and $X_{e q}$ represent the dry basis moisture content (kg water/ kg dry solid) at any time, initial and equilibrium, respectively. The dry basis moisture content of apple slices can be calculated based on Equation (2):

$$
X=\frac{m_{\mathrm{H}_{2} \mathrm{O}}}{m_{d r y}}=\frac{m_{\text {weet }}-m_{d r y}}{m_{d r y}}
$$

where $m_{H 2 O}$ is the actual mass of water in the wet solid, $m_{\text {wet }}$ is the total mass of the wet solid and $m_{d r y}$ is the mass of dry matter [41,42].

A disadvantage of these simple thin-layer models is that different parameters of the model are required for different process conditions. This fact limits the use of such models to conditions for which the model parameters were estimated. For this reason, a new four-parametric model containing information on process conditions was developed. The presented model, referred to here as Haydary, is sensible to process conditions and works with four process parameters and four empirical parameters determined based on 3780 experimental points optimized for all process conditions. The process parameters included are temperature, air velocity, air relative humidity and layer thickness. The model is represented by Equation (3)

$$
\left.M R=\operatorname{EXP}\left[-k\left(\frac{T / T_{\min } v / v_{\min }}{d / d_{\min } \varphi / \varphi_{\min }}\right)^{p} t^{n\left(\frac{T / T_{\min }}{d / d_{\min }} \varphi / /_{\text {min }}\right.}\right)^{r}\right]
$$

where $k, p, r$ and $n$ are empirical parameters, $T$ is temperature, $v$ air velocity, $d$ sample thickness, $\varphi$ is air relative humidity, $T_{\min }, v_{\min }, d_{\min }$ and $\varphi_{\min }$ are minimum values of parameters in their measurement ranges. The advantage of this model is its applicability as a single equation for all process conditions inside their defined ranges.

Thin-layer drying can be modeled also by simplification of Fick's second law equation. The simplified equation has been applied by many authors [43-45] for the determination of the effective diffusion coefficient of water $\left(D_{e f f}\right)$ in sliced materials:

$$
M R=\sum_{n=0}^{\infty} \frac{8}{(2 n+1)^{2} \pi^{2}} \operatorname{Exp}\left(-\frac{(2 n+1)^{2} \pi^{2} D_{e f f} t}{4 l^{2}}\right)
$$

where $M R$ is the moisture ratio defined by Equation (1), $t$ is time and $l$ is half of the slice thickness.

For long drying times, only one term of Equation (1) can be considered:

$$
M R=\frac{8}{\pi^{2}} \operatorname{Exp}\left(-\frac{\pi^{2} D_{e f f} t}{4 l^{2}}\right)
$$

The effective diffusion coefficient $D_{\text {eff }}$ can be determined from the slope of the linear dependence of $\ln (M R)$ versus time using experimental data:

$$
\ln (M R)=\ln \frac{8}{\pi^{2}}+\left(-\frac{\pi^{2} D_{e f f}}{4 l^{2}}\right) t
$$

\subsection{Statistical Analysis}

For mathematical modeling, the thin-layer drying equations shown in Table 2 were used to select a suitable model for apple dying according to the experimental data. There are three important statistical parameters helpful for choosing the best model, such as the coefficient of determination 
$\left(R^{2}\right)$ (Equation (7)), reduced chi-square $\left(X^{2}\right)$ (Equation (8)) and root mean square error (RMES) (Equation (9)) $[29,46,47]$. For the calculation of empirical constants' values, a solver from Microsoft Excel was used.

$$
\begin{aligned}
R^{2} & =1-\frac{\sum_{i-1}^{n}\left(M R_{\text {exp }, i}-M R_{\text {pre }, i}\right)^{2}}{\sum_{i-1}^{n}\left(M R_{\text {exp }, i}-M R_{\text {exp }}\right)^{2}} \\
X^{2} & =\frac{\sum_{i-1}^{n}\left(M R_{\text {exp }, i}-M R_{\text {pre }, i}\right)^{2}}{N-Z} \\
R M S E & =\left[\frac{1}{N} \sum_{i=1}^{n}\left(M R_{\text {exp }, i}-M R_{\text {pre }, i}\right)^{2}\right]^{1 / 2}
\end{aligned}
$$

In these equations, $M R_{\text {exp }, i}$ represents the $i^{\text {th }}$ experimentally observed normalized moisture ratio, $M R_{\text {pre }, i}$ represents the $i^{t h}$ predicted value, $M R_{\text {exp }}$ is average of normalized $M R$ of experimental points, $N$ is the number of observations and $z$ is the number of constants in the models.

By statistical analysis of thin-layer mathematical modeling, the coefficient of determination $\left(R^{2}\right)$ is the main criterion for the selection of the most suitable model to describe the drying curve equation [36]. In addition, the mean square of the deviations $\left(X^{2}\right)$, according to the predicted and experimental values and the root mean square error analysis (RMSE), are also important for the selection of a suitable model [24,48].

\section{Results and Discussion}

\subsection{Effect of Conditions on Drying Kinetics}

Substituting the experimentally obtained data of sample mass loss and Equations (1) and (2), the sample transient moisture content (d.b) and moisture ratio $(M R)$ were calculated. Drying curves, given as variations of moisture content (d.b) with time measured at different conditions, were compared. In all cases, up to $96 \%$ of the total water content in apples evaporated during the experiment. Figure 3 shows the effect of air velocity at $50^{\circ} \mathrm{C}$. Air velocity has a significant effect on drying kinetics. Increasing the air velocity from 0.60 to $1.1 \mathrm{~m} / \mathrm{s}$, the drying time decreased by about $100 \mathrm{~min}$; similar results were achieved at the other two temperatures.

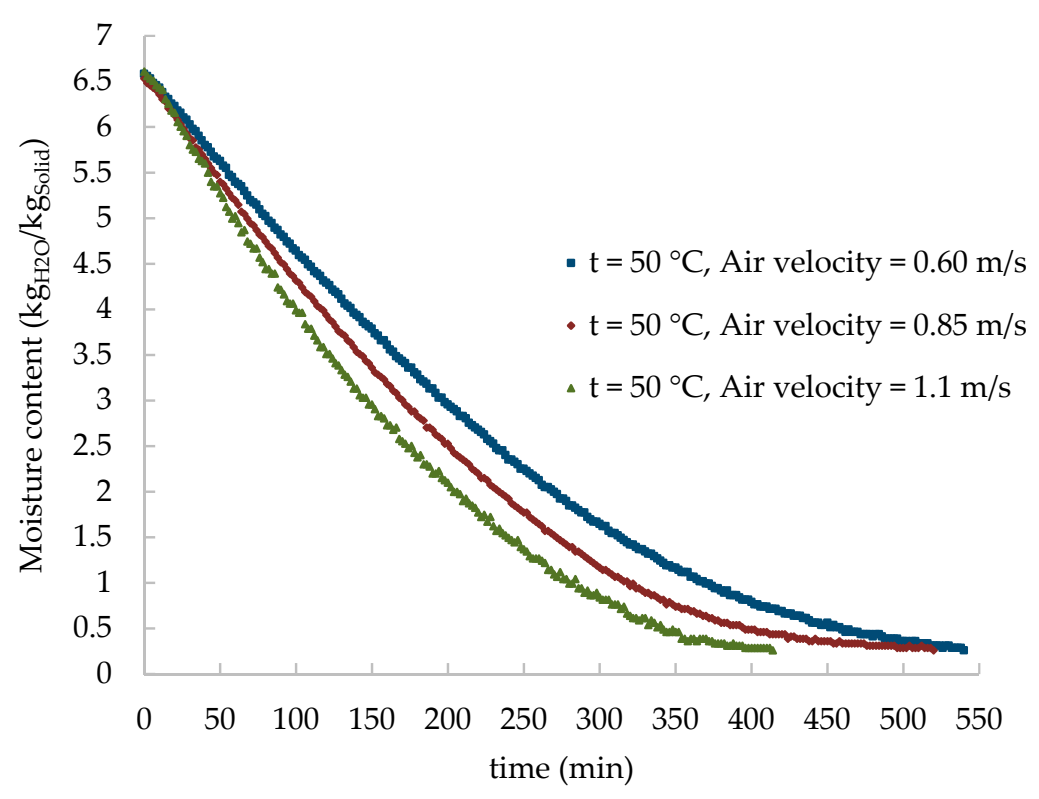

Figure 3. Effect of air velocity on dry basis moisture content $(X)$. 
The change of the moisture content with time at different temperatures, from 40 to $50{ }^{\circ} \mathrm{C}$, at an air velocity of $1.1 \mathrm{~m} / \mathrm{s}$ is shown in Figure 4 . The effect of temperature is crucial. By increasing the temperature in the drying chamber from 40 to $50{ }^{\circ} \mathrm{C}$ at an air velocity of $1.1 \mathrm{~m} / \mathrm{s}$, the drying time decreased by about $300 \mathrm{~min}$. A comparable effect of temperature and air velocity was also reported by other authors $[13,14]$.

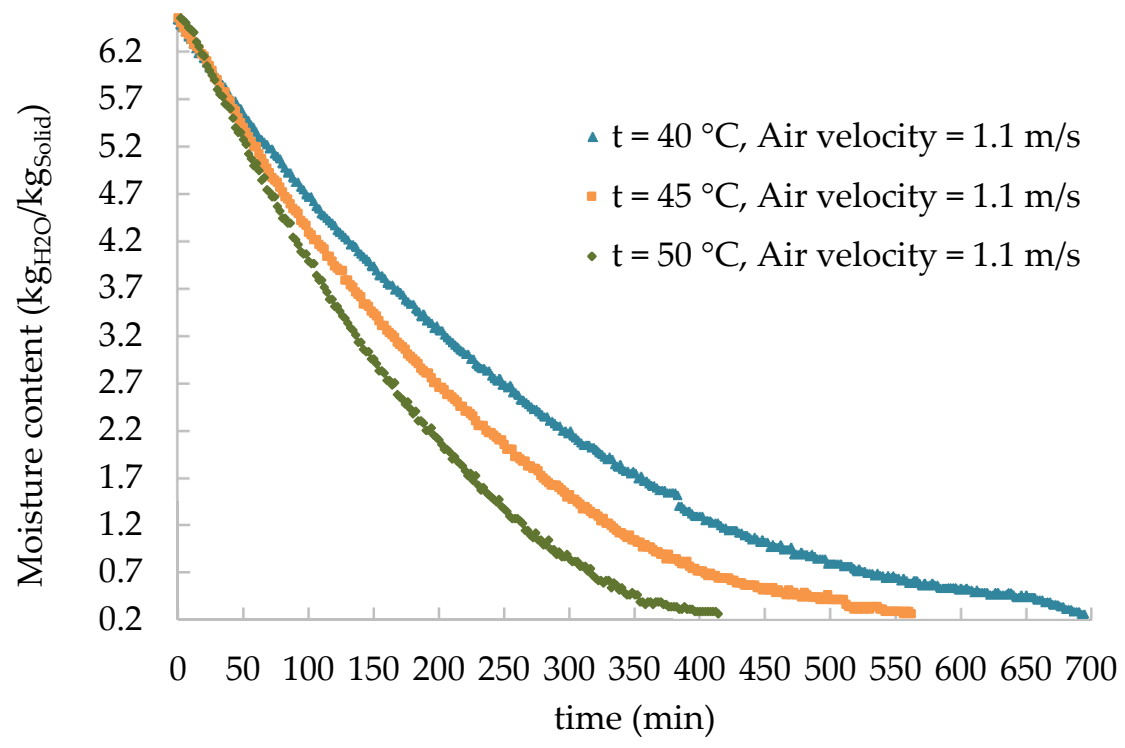

Figure 4. Effect of temperature on dry basis moisture content (X).

Ambient air relative humidity can also significantly affect the drying rate. To observe the effect of ambient air relative humidity, the experiments at constant temperature and air velocity were repeated during different seasons with ambient air relative humidity, $25-28 \%, 35-38 \%$ and $40-45 \%$, respectively. Removal of the moisture content of apple slices was faster at lower ambient air relative humidity, as shown in Figure 5.

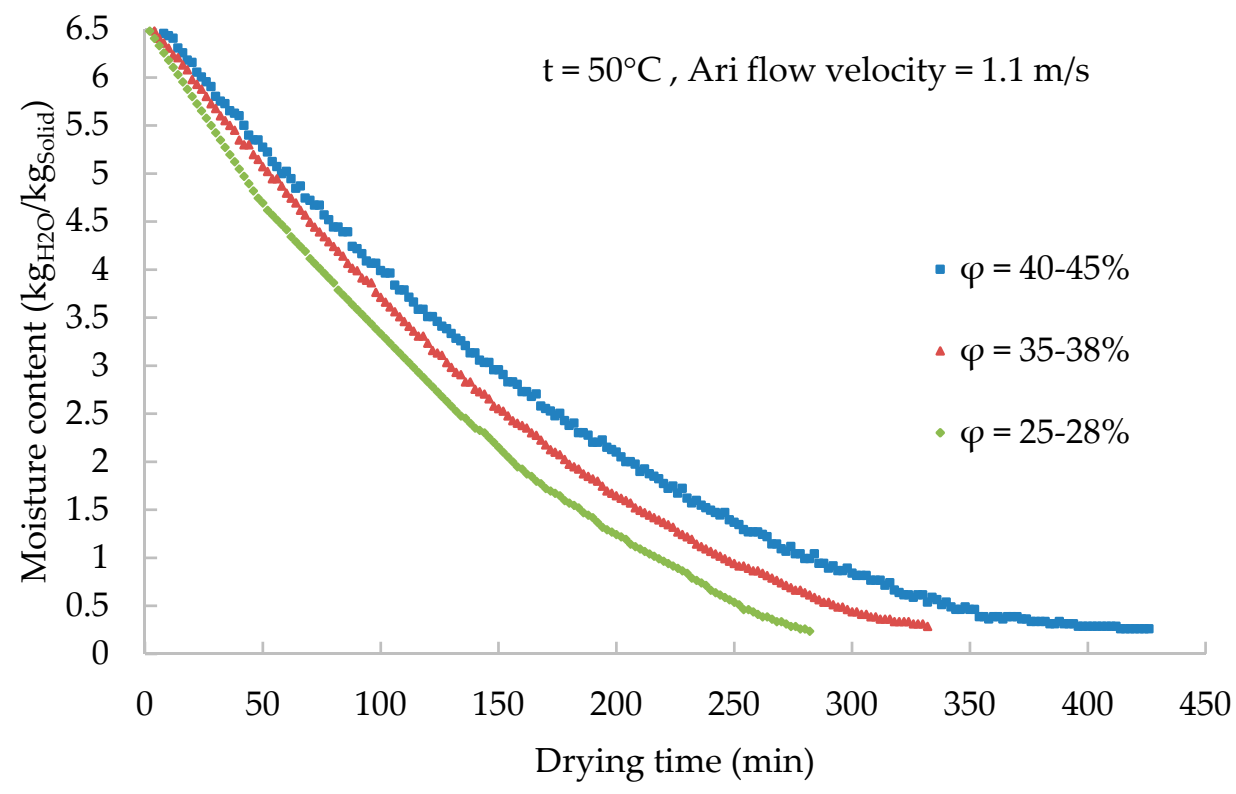

Figure 5. Effect of air relative humidity.

Slice thickness has a significant effect on drying kinetics. While for $4 \mathrm{~mm}$ slices, the required degree of drying was achieved after $300 \mathrm{~min}$; for $12 \mathrm{~mm}$ slices, one working day (maximum $10 \mathrm{~h}$ ) 
was not enough and measurement was stopped after $8.5 \mathrm{~h}$ and continued on the second day. This is the reason of the break on the curve for $12 \mathrm{~mm}$ slices in Figure 6. At high moisture content (at the beginning of the experiment) when free water from the apples is evaporated, the effect of slice thickness is not significant; however, by decreasing the moisture content, the drying rate is limited by water diffusion to the surface and the effect of slice thickness becomes crucial.

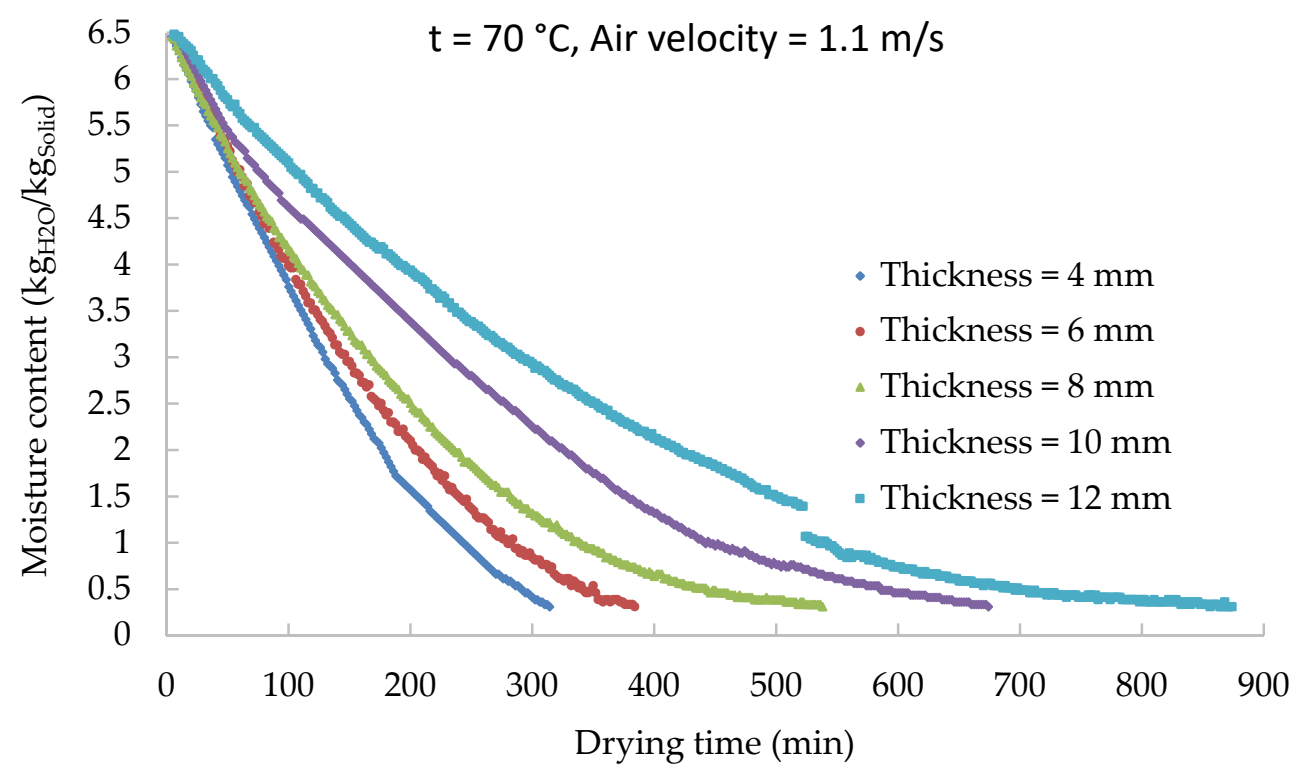

Figure 6. Effect of slice thickness.

\subsection{Mathematical Model Selection}

Using thin-layer empirical models given in Table 2, parameters of all five (Newton, Page, modified Page, logarithmic and Henderson and Pabis) models were estimated by fitting the calculated data to the experimentally measured ones. An example of graphical comparison of calculated and measured data at $45^{\circ} \mathrm{C}$, air velocity of $0.85 \mathrm{~m} / \mathrm{s}$ and sample thickness of $6 \mathrm{~mm}$ is given in Figure 7 .
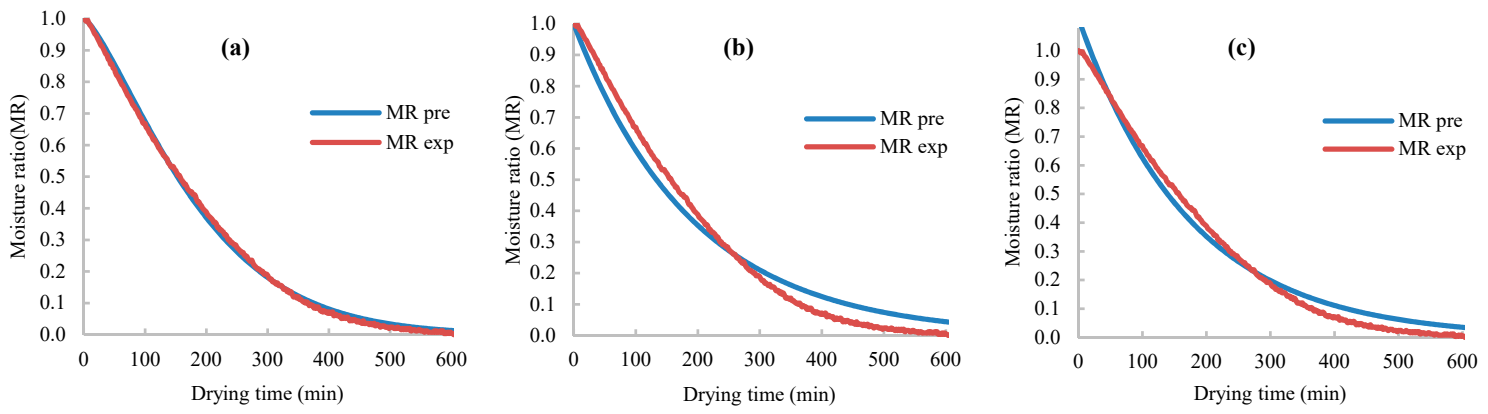

Figure 7. Comparison of experimental and calculated $M R\left(45^{\circ} \mathrm{C}, 0.20 \mathrm{~m} / \mathrm{s} 6 \mathrm{~mm}\right)$ : (a)-Page model, (b)-Newton (Lewis) model and (c)-Henderson and Pabis model.

Statistical analysis was done to select the most appropriate thin-layer empirical model for drying apple slices at different conditions. The analysis was conducted to decide the most suitable model with the highest value of $R^{2}$ (Equation (6)) and the lowest values of $X^{2}$ (Equation (7)) and RMSE (Equation (8)). The model with the highest $R^{2}$ and the lowest $X^{2}$ and MRSE is best suitable to describe the drying process $[28,49]$.

All five models were run at all conditions: three temperature levels: 40,45 and $50{ }^{\circ} \mathrm{C}$, three air velocity values: $0.60,0.85$ and $1.1 \mathrm{~m} / \mathrm{s}$ with $6 \mathrm{~mm}$ apple slice thicknesses (Table 3 ) and as well for five additional thicknesses of 4, 6, 8, 10 and $12 \mathrm{~mm}$ (Table 4), and three ambient air relative humidity values at $50{ }^{\circ} \mathrm{C}$, a $1.1 \mathrm{~m} / \mathrm{s}$ rate and a thickness of $6 \mathrm{~mm}$ (Table 5). 
Table 3. Summary of the regression analysis of apple slices with a $6 \mathrm{~mm}$ thickness.

\begin{tabular}{|c|c|c|c|c|c|c|c|}
\hline Model & $\begin{array}{c}\text { Drying } \\
\text { Temperature } \\
\left({ }^{\circ} \mathrm{C}\right)\end{array}$ & $\begin{array}{l}\text { Air flow } \\
\text { Velocity } \\
(\mathrm{m} / \mathrm{s})\end{array}$ & $\begin{array}{c}\text { Drying } \\
\text { Constant } \\
(k)\end{array}$ & $\begin{array}{c}\text { Drying } \\
\text { Coefficient } \\
(n, a, c)\end{array}$ & $R^{2}$ & $X^{2}$ & RMSE \\
\hline \multirow{3}{*}{ Newton } & 40 & 0.60 & 0.00336 & - & 0.97296 & 0.00242 & 0.04908 \\
\hline & 45 & 0.60 & 0.00382 & - & 0.96203 & 0.00351 & 0.05917 \\
\hline & 50 & 0.60 & 0.00479 & - & 0.96515 & 0.00313 & 0.05586 \\
\hline \multirow{3}{*}{ Page } & 40 & 0.60 & 0.00049 & 1.32869 & 0.99817 & 0.00016 & 0.01278 \\
\hline & 45 & 0.60 & 0.00040 & 1.39538 & 0.99549 & 0.00042 & 0.02039 \\
\hline & 50 & 0.60 & 0.00060 & 1.37892 & 0.99643 & 0.00032 & 0.01788 \\
\hline \multirow{3}{*}{$\begin{array}{l}\text { Modified } \\
\text { Page }\end{array}$} & 40 & 0.60 & 0.00289 & 1.16368 & 0.97296 & 0.00242 & 0.04908 \\
\hline & 45 & 0.60 & 0.00308 & 1.23968 & 0.96203 & 0.00098 & 0.05917 \\
\hline & 50 & 0.60 & 0.00345 & 1.38842 & 0.96515 & 0.00314 & 0.05586 \\
\hline \multirow{3}{*}{ Logarithmic } & 40 & 0.60 & 0.00371 & 1.10563 & 0.98434 & 0.00141 & 0.03736 \\
\hline & 45 & 0.60 & 0.00423 & 1.11139 & 0.97498 & 0.00233 & 0.04803 \\
\hline & 50 & 0.60 & 0.00531 & 1.11041 & 0.97776 & 0.00201 & 0.04462 \\
\hline \multirow{3}{*}{$\begin{array}{l}\text { Henderson } \\
\text { and Pabis }\end{array}$} & 40 & 0.60 & 0.00371 & 1.10565 & 0.98434 & 0.00140 & 0.03736 \\
\hline & 45 & 0.60 & 0.00423 & 1.11139 & 0.97498 & 0.00232 & 0.04803 \\
\hline & 50 & 0.60 & 0.00531 & 1.11041 & 0.97776 & 0.00201 & 0.04462 \\
\hline \multirow{3}{*}{ Newton } & 40 & 0.85 & 0.00380 & - & 0.98540 & 0.06675 & 0.03117 \\
\hline & 45 & 0.85 & 0.00520 & - & 0.97407 & 0.00236 & 0.04846 \\
\hline & 50 & 0.85 & 0.00558 & - & 0.96617 & 0.00317 & 0.05619 \\
\hline \multirow{3}{*}{ Page } & 40 & 0.85 & 0.00120 & 1.20096 & 0.99895 & 0.00007 & 0.00834 \\
\hline & 45 & 0.85 & 0.00083 & 1.33731 & 0.99848 & 0.00014 & 0.01174 \\
\hline & 50 & 0.85 & 0.00072 & 1.38314 & 0.99658 & 0.00032 & 0.01788 \\
\hline \multirow{3}{*}{$\begin{array}{l}\text { Modified } \\
\text { Page }\end{array}$} & 40 & 0.85 & 0.00307 & 1.23618 & 0.80533 & 0.00098 & 0.03117 \\
\hline & 45 & 0.85 & 0.00359 & 1.44698 & 0.97407 & 0.00236 & 0.04846 \\
\hline & 50 & 0.85 & 0.00372 & 1.49887 & 0.96617 & 0.00318 & 0.05619 \\
\hline \multirow{3}{*}{ Logarithmic } & 40 & 0.85 & 0.00406 & 1.06945 & 0.99304 & 0.00047 & 0.02152 \\
\hline & 45 & 0.85 & 0.00575 & 1.11311 & 0.98542 & 0.00133 & 0.03635 \\
\hline & 50 & 0.85 & 0.00618 & 1.11459 & 0.97840 & 0.00204 & 0.04490 \\
\hline \multirow{3}{*}{$\begin{array}{l}\text { Henderson } \\
\text { and Pabis }\end{array}$} & 40 & 0.85 & 0.00406 & 1.06945 & 0.99304 & 0.00047 & 0.02152 \\
\hline & 45 & 0.85 & 0.00575 & 1.11311 & 0.98542 & 0.00133 & 0.03635 \\
\hline & 50 & 0.85 & 0.00618 & 1.11459 & 0.97840 & 0.00203 & 0.04490 \\
\hline \multirow{3}{*}{ Newton } & 40 & 1.10 & 0.00412 & - & 0.98471 & 0.00125 & 0.03532 \\
\hline & 45 & 1.10 & 0.00521 & - & 0.97948 & 0.00177 & 0.04198 \\
\hline & 50 & 1.10 & 0.00642 & - & 0.96824 & 0.00266 & 0.05148 \\
\hline \multirow{3}{*}{ Page } & 40 & 1.10 & 0.00105 & 1.25230 & 0.99442 & 0.00046 & 0.02133 \\
\hline & 45 & 1.10 & 0.00124 & 1.26371 & 0.99687 & 0.00027 & 0.01638 \\
\hline & 50 & 1.10 & 0.00109 & 1.34141 & 0.99522 & 0.00040 & 0.01998 \\
\hline \multirow{3}{*}{$\begin{array}{l}\text { Modified } \\
\text { Page }\end{array}$} & 40 & 1.10 & 0.00328 & 1.31841 & 0.98245 & 0.00144 & 0.03785 \\
\hline & 45 & 1.10 & 0.00360 & 1.44849 & 0.97948 & 0.00178 & 0.04198 \\
\hline & 50 & 1.10 & 0.00399 & 1.60718 & 0.96824 & 0.00268 & 0.05148 \\
\hline \multirow{3}{*}{ Logarithmic } & 40 & 1.10 & 0.00463 & 1.07414 & 0.98693 & 0.00108 & 0.03266 \\
\hline & 45 & 1.10 & 0.00564 & 1.08396 & 0.98652 & 0.00117 & 0.03403 \\
\hline & 50 & 1.10 & 0.00707 & 1.10481 & 0.97972 & 0.00172 & 0.04113 \\
\hline \multirow{3}{*}{$\begin{array}{l}\text { Henderson } \\
\text { and Pabis }\end{array}$} & 40 & 1.10 & 0.00463 & 1.07412 & 0.98692 & 0.00107 & 0.03267 \\
\hline & 45 & 1.10 & 0.00564 & 1.08396 & 0.98652 & 0.00117 & 0.03403 \\
\hline & 50 & 1.10 & 0.00707 & 1.10480 & 0.97972 & 0.00171 & 0.04113 \\
\hline
\end{tabular}


Table 4. Summary of the regression analysis of apple slices with 4, 6, 8, 10 and $12 \mathrm{~mm}$ thicknesses at 50 ${ }^{\circ} \mathrm{C}$ and air flow velocity $1.1 \mathrm{~m} / \mathrm{s}$.

\begin{tabular}{|c|c|c|c|c|c|c|}
\hline Model & $\begin{array}{l}\text { Thickness } \\
(\mathrm{mm})\end{array}$ & $\begin{array}{l}\text { Drying Constant } \\
(k)\end{array}$ & $\begin{array}{l}\text { Drying Coefficient } \\
\qquad(n, a, c)\end{array}$ & $R^{2}$ & $X^{2}$ & $R M S E$ \\
\hline \multirow{5}{*}{ Newton } & 4 & 0.00725 & - & 0.95970 & 0.00366 & 0.06029 \\
\hline & 6 & 0.00644 & - & 0.96797 & 0.00288 & 0.05355 \\
\hline & 8 & 0.00540 & - & 0.98094 & 0.00163 & 0.04036 \\
\hline & 10 & 0.00417 & - & 0.97879 & 0.00175 & 0.04172 \\
\hline & 12 & 0.00330 & - & 0.96746 & 0.00288 & 0.05362 \\
\hline \multirow{5}{*}{ Page } & 4 & 0.00097 & 1.40099 & 0.99473 & 0.00048 & 0.02180 \\
\hline & 6 & 0.00110 & 1.34178 & 0.99534 & 0.00042 & 0.02042 \\
\hline & 8 & 0.00138 & 1.25262 & 0.99694 & 0.00026 & 0.01617 \\
\hline & 10 & 0.00118 & 1.22320 & 0.99210 & 0.00065 & 0.02546 \\
\hline & 12 & 0.00056 & 1.30152 & 0.98886 & 0.00099 & 0.03137 \\
\hline \multirow{5}{*}{$\begin{array}{l}\text { Modified } \\
\text { Page }\end{array}$} & 4 & 0.00498 & 1.45533 & 0.95970 & 0.00368 & 0.06029 \\
\hline & 6 & 0.00400 & 1.61058 & 0.96797 & 0.00290 & 0.05355 \\
\hline & 8 & 0.00366 & 1.47381 & 0.98094 & 0.00164 & 0.04036 \\
\hline & 10 & 0.00322 & 1.29577 & 0.97879 & 0.00175 & 0.04172 \\
\hline & 12 & 0.00286 & 1.15224 & 0.96746 & 0.00289 & 0.05362 \\
\hline \multirow{5}{*}{ Logarithmic } & 4 & 0.00804 & 1.10655 & 0.97304 & 0.00248 & 0.04931 \\
\hline & 6 & 0.00711 & 1.10273 & 0.97960 & 0.00186 & 0.04274 \\
\hline & 8 & 0.00582 & 1.08208 & 0.98748 & 0.00108 & 0.03270 \\
\hline & 10 & 0.00440 & 1.05694 & 0.98233 & 0.00146 & 0.03808 \\
\hline & 12 & 0.00357 & 1.08547 & 0.97469 & 0.00225 & 0.04729 \\
\hline \multirow{5}{*}{$\begin{array}{l}\text { Henderson } \\
\text { and Pabis }\end{array}$} & 4 & 0.00804 & 1.10655 & 0.97304 & 0.00246 & 0.04931 \\
\hline & 6 & 0.00711 & 1.10273 & 0.97960 & 0.00185 & 0.04274 \\
\hline & 8 & 0.00582 & 1.08208 & 0.98748 & 0.00108 & 0.03270 \\
\hline & 10 & 0.00440 & 1.05694 & 0.98233 & 0.00146 & 0.03808 \\
\hline & 12 & 0.00357 & 1.08547 & 0.97469 & 0.00225 & 0.04729 \\
\hline
\end{tabular}

Table 5. Summary of the regression analysis of apple slices at $50{ }^{\circ} \mathrm{C}$ and air flow velocity of $1.1 \mathrm{~m} / \mathrm{s}$ and three ranges of ambient relative humidity.

\begin{tabular}{ccccccc}
\hline \multirow{2}{*}{ Model } & $\begin{array}{c}\text { Relative } \\
\text { Humidity (\%) }\end{array}$ & $\begin{array}{c}\text { Drying Constant } \\
(\boldsymbol{k})\end{array}$ & $\begin{array}{c}\text { Drying Coefficient } \\
(\boldsymbol{n}, \boldsymbol{a}, \boldsymbol{c})\end{array}$ & $\boldsymbol{R}^{\mathbf{2}}$ & $\boldsymbol{X}^{\mathbf{2}}$ & $\boldsymbol{R} \boldsymbol{R} \boldsymbol{}$ \\
\hline \multirow{3}{*}{ Newton } & $25-28$ & 0.00823 & - & 0.97114 & 0.00248 & 0.04962 \\
& $35-38$ & 0.00668 & - & 0.97523 & 0.00220 & 0.04672 \\
& $40-45$ & 0.00642 & - & 0.96824 & 0.00266 & 0.05148 \\
\hline \multirow{2}{*}{ Page } & $25-28$ & 0.00198 & 1.29042 & 0.99231 & 0.00067 & 0.02561 \\
& $35-38$ & 0.00141 & 1.30652 & 0.99775 & 0.00020 & 0.01407 \\
& $40-45$ & 0.00109 & 1.34141 & 0.99522 & 0.00040 & 0.01998 \\
\hline \multirow{2}{*}{ Modified } & $25-28$ & 0.00452 & 1.82000 & 0.97114 & 0.00250 & 0.04962 \\
Page & $35-38$ & 0.00407 & 1.64022 & 0.97523 & 0.00221 & 0.04672 \\
& $40-45$ & 0.00399 & 1.60718 & 0.96824 & 0.00268 & 0.05148 \\
\hline \multirow{2}{*}{ Logarithmic } & $25-28$ & 0.00888 & 1.07675 & 0.97839 & 0.00188 & 0.04294 \\
& $35-38$ & 0.00732 & 1.09008 & 0.98503 & 0.00134 & 0.03631 \\
& $40-45$ & 0.00707 & 1.10481 & 0.97972 & 0.00172 & 0.04113 \\
\hline \multirow{2}{*}{ Henderson } & $25-28$ & 0.00888 & 1.07676 & 0.97839 & 0.00187 & 0.04294 \\
and Pabis & $35-38$ & 0.00732 & 1.09007 & 0.98503 & 0.00133 & 0.03631 \\
& $40-45$ & 0.00707 & 1.10480 & 0.97972 & 0.00171 & 0.04113 \\
\hline
\end{tabular}

Between these simple thin-layer models, in all cases, the Page model was identified as the most suitable model with the highest values of $R^{2}$ and lowest values of $X^{2}$ and RMSE. The other four models provided similar results, but their performance was less compared to the Page model. The Page empirical model is a simple model with two constants, $k$ and $n$. As shown in Tables 3-5, the values of both constants were affected by the process conditions. Since both parameters are optimized 
simultaneously to fit experimental data, exact correlations between process conditions and model parameters were not found.

As mentioned above, a disadvantage of these simple thin-layer models is the requirement for different parameters of the model for different process conditions. The new model developed in this work (Haydary) is represented by a single equation valid for all process conditions. Table 6 shows parameters of the model, the range of process conditions and parameters of statistical analysis for this model. Compared to simple thin-layer models valid for only a single process condition, this model shows a slightly lower $R^{2}$ and higher $X^{2}$ and RMSE. However, considering its wide range of applicability, these differences do not represent a significant disadvantage.

Table 6. Parameters and statistical analysis of the model developed in this work (Haydary).

\begin{tabular}{|c|c|c|c|c|}
\hline Model & $\begin{array}{c}\text { Drying } \\
\text { Temperature Range } \\
\left({ }^{\circ} \mathrm{C}\right)\end{array}$ & $\begin{array}{l}\text { Air velocity Range } \\
(\mathrm{m} / \mathrm{s})\end{array}$ & $\begin{array}{l}\text { Thickness Range } \\
\text { (mm) }\end{array}$ & $\begin{array}{c}\text { Air relative } \\
\text { Humidity Range } \\
(\%)\end{array}$ \\
\hline \multirow{7}{*}{ Haydary } & $40-50$ & $0.6-1.1$ & $4-12$ & $27.5-42.5$ \\
\hline & $\begin{array}{l}T_{\min } \\
\left({ }^{\circ} \mathrm{C}\right)\end{array}$ & $\begin{array}{c}v_{\min } \\
(\mathrm{m} / \mathrm{s})\end{array}$ & $\begin{array}{c}d_{\min } \\
(\mathrm{mm})\end{array}$ & $\begin{array}{c}\varphi_{\min } \\
(\%)\end{array}$ \\
\hline & 40 & 0.6 & 4 & 27.5 \\
\hline & $k$ & $p$ & $n$ & $r$ \\
\hline & 0.001357 & 1.287293 & 0.72286 & 0.018861 \\
\hline & $R^{2}$ & $X^{2}$ & RMSE & - \\
\hline & 0.977496 & 0.002001 & 0.044714 & - \\
\hline
\end{tabular}

\subsection{Effective Diffusion Coefficient $D_{\text {eff }}$}

The effective diffusion coefficient of water in an apple slice was estimated under all measurement conditions using only one term of the simplified Fick's equation. The data recorded in the first $300 \mathrm{~min}$ were included in the calculation of $D_{\text {eff. }}$. The values of $D_{\text {eff }}$ varied between $1.9 \times 10^{-10}$ and $7.0 \times 10^{-10}$ $\mathrm{m}^{2} / \mathrm{s}$. Sacilik et al. [50] reported values between $2.27 \times 10^{-10}$ and $4.97 \times 10^{-10} \mathrm{~m}^{2} / \mathrm{s}$ for drying apple slices under conditions similar to those in this work. Comparable value of $D_{\text {eff }}$ at $45^{\circ} \mathrm{C}$ and air relative humidity of $40 \%$ was also measured by Kaya et al. [45]. Figure 8 shows the effect of temperature and air velocity on the effective diffusion coefficient. Increasing the temperature and air velocity leads to more intensive diffusion of water and a higher $D_{\text {eff. }}$. From Figure 8, results show that the effect of air velocity is more significant at higher temperatures. Similar correlations were found by other authors $[16,37,51]$.

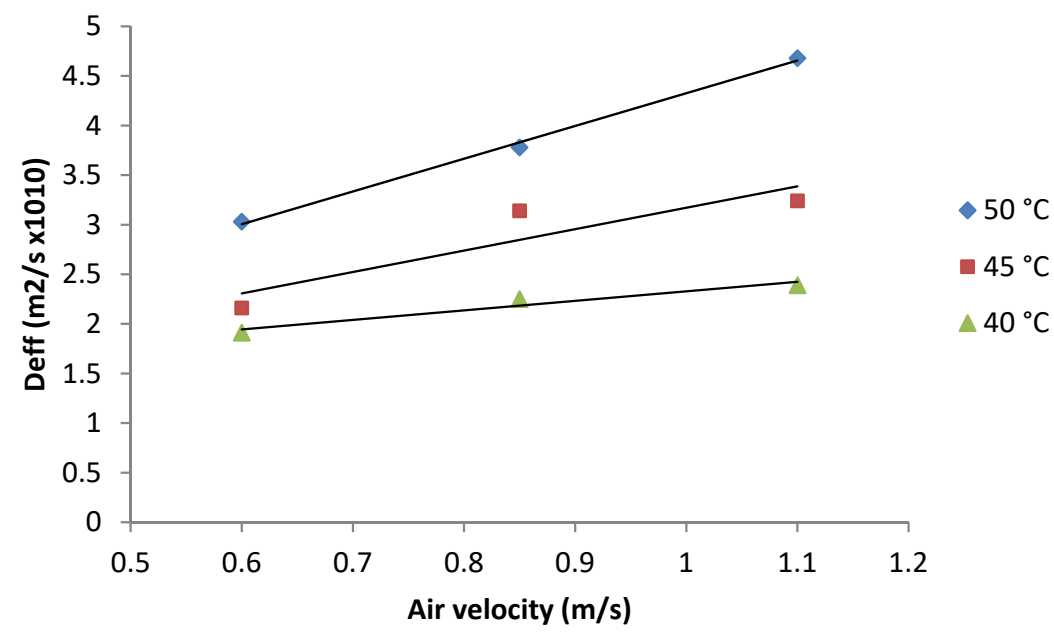

Figure 8. Effective diffusion coefficient vs. temperature and air velocity. 
An increase in the slice thickness led to an increased effective diffusion coefficient. However, as shown in the results from Figure 9, this increase is not linear. The diffusion coefficient is an intrinsic property of the material and it is not expected to change with its thickness; however, the effective diffusion coefficient is influenced by the process conditions. Smaller effects of slice thickness on $D_{\text {eff }}$ can be related to less significant effects of process conditions at higher thicknesses.

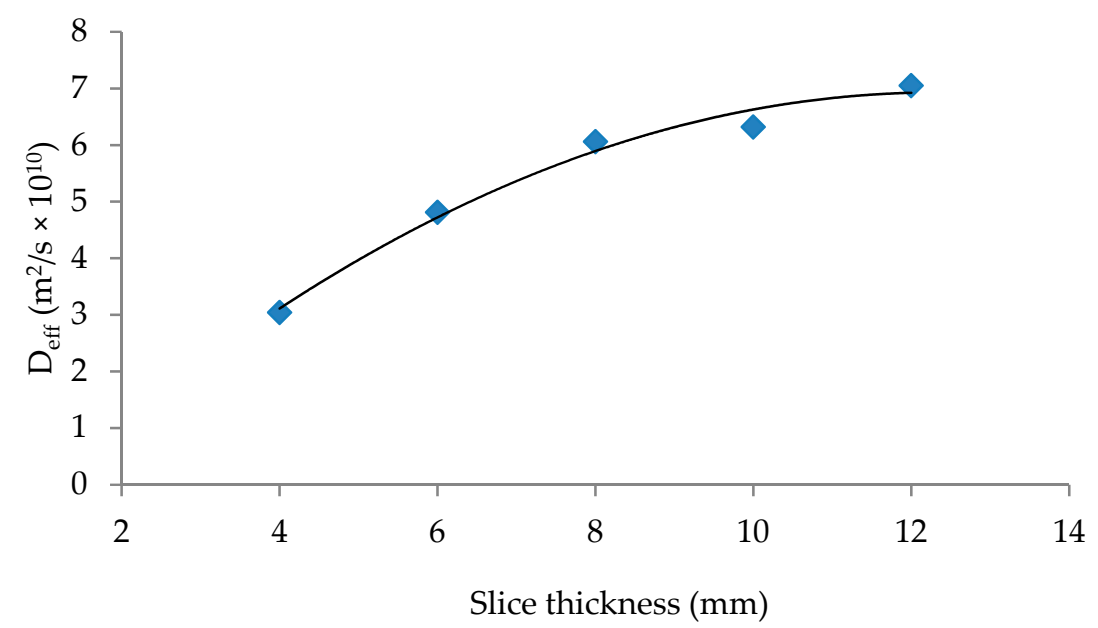

Figure 9. Effective diffusion coefficient vs. slice thickness.

At $50{ }^{\circ} \mathrm{C}$, with air velocity of $1.1 \mathrm{~m} / \mathrm{s}$ and air relative humidity of $40-45 \%$, the value of $D_{\text {eff }}$ was $4.68 \times 10^{-10} \mathrm{~m}^{2} / \mathrm{s}$; it increased to $4.93 \times 10^{-10}$ and $6.16 \times 10^{-10} \mathrm{~m}^{2} / \mathrm{s}$ when the air relative humidity decreased to $35-40 \%$ and $25-28 \%$, respectively.

\subsection{Water Activity Measurement}

Water activity of the sample during the experiments at temperatures of 40,45 and $50{ }^{\circ} \mathrm{C}$ and air velocities of 0.85 and $1.1 \mathrm{~m} / \mathrm{s}$ for each temperature, was estimated. The measurements were done every 60 min during each experiment. As shown in Figure 10, during the initial drying phase when free water is evaporated from the slices, water activity remains practically constant. After the evaporation of the free water, the product water activity rapidly decreases. The rate of the value drop is higher at higher temperatures and higher air velocity because of faster water evaporation.

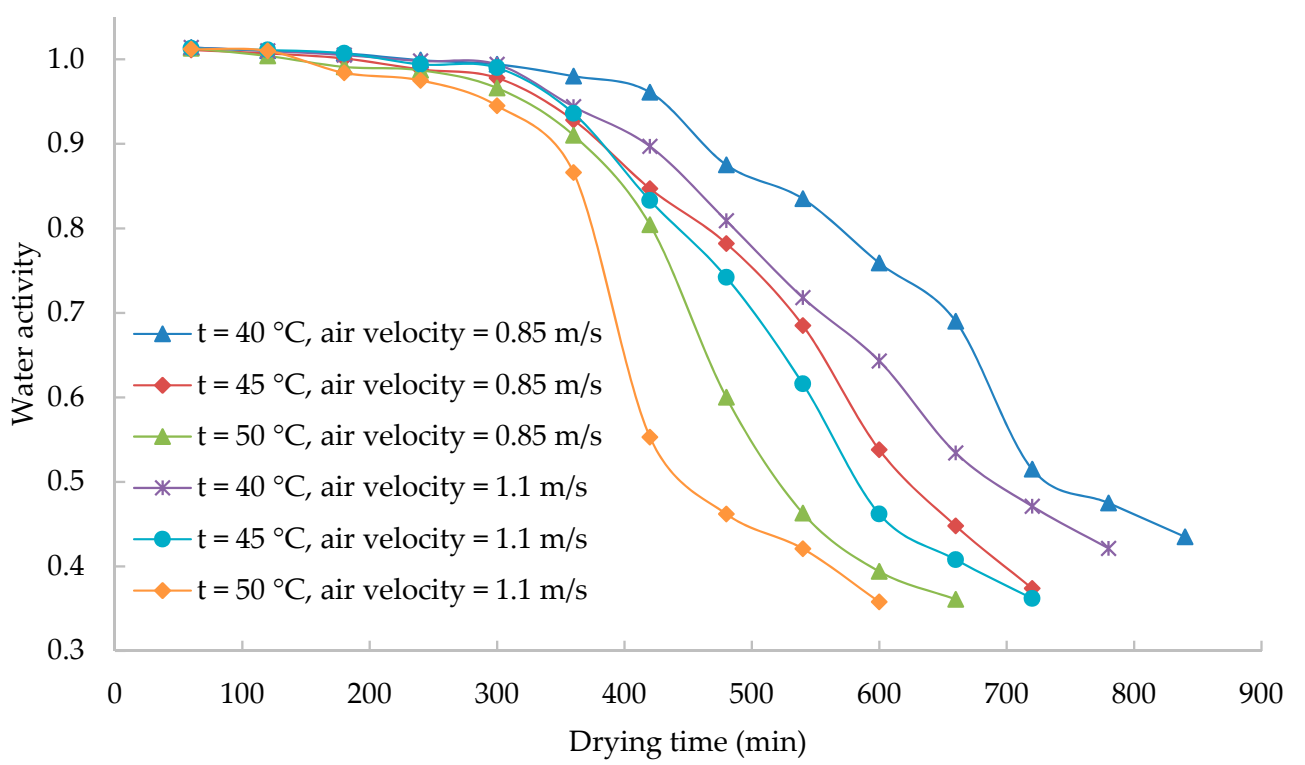

Figure 10. Variation of water activity versus drying time at different temperatures and air velocities. 
Water activity is an important parameter for drying time optimization and product preservation. Generally, water activity of 0.6 is considered to be a critical point with high potential for microbe growth [52]. Figure 10 shows that at high drying rates (high temperatures, high air velocities, low air relative humidity), a small change in the drying time can significantly influence the product water activity. Therefore, water activity of 0.45 was selected and the required drying time to reach the value of $0.45 \pm 0.05$ for all studied conditions was estimated. The results are presented in Tables 7-9. The shortest drying time $(4.7 \mathrm{~h})$ was recorded for $6 \mathrm{~mm}$ slices dried at $50{ }^{\circ} \mathrm{C}$, with an air velocity of $1.1 \mathrm{~m} / \mathrm{s}$ and an ambient air relative humidity range of $25-28 \%$. The longest drying time with the same slice thickness was $13.33 \mathrm{~h}$, which was recorded at $40{ }^{\circ} \mathrm{C}$, with an air velocity $0.60 \mathrm{~m} / \mathrm{s}$ and an air relative humidity range of $40-45 \%$. Increasing of air temperature and air velocity leads to more intensive evaporation of water from the surface of apple slices; consequently it results in increased effective diffusion coefficient of water [15]. More intensive diffusion of water inside the slices and more intensive evaporation of water from the slice surface enables reaching the required water activity in a shorter time.

Table 7. Effect of air temperature and air flow velocity on the drying time.

\begin{tabular}{cccccc}
\hline Exp. Run & $\begin{array}{c}\text { Temperature } \\
\left({ }^{\circ} \mathbf{C}\right)\end{array}$ & $\begin{array}{c}\text { Air Velocity } \\
\mathbf{m} / \mathbf{s}\end{array}$ & $\begin{array}{c}\text { Thickness } \\
\mathbf{( m m )}\end{array}$ & $\begin{array}{c}\text { Relative } \\
\text { Humidity (\%) }\end{array}$ & $\begin{array}{c}\text { Drying } \\
\text { Time (h) }\end{array}$ \\
\hline 1 & 40 & 0.60 & 6 & $40-45$ & 13.33 \\
2 & 45 & 0.60 & 6 & $40-45$ & 11.10 \\
3 & 50 & 0.60 & 6 & $40-45$ & 9.00 \\
4 & 40 & 0.85 & 6 & $40-45$ & 12.20 \\
5 & 45 & 0.85 & 6 & $40-45$ & 10.07 \\
6 & 50 & 0.85 & 6 & $40-45$ & 8.67 \\
7 & 40 & 1.10 & 6 & $40-45$ & 11.57 \\
8 & 45 & 1.10 & 6 & $40-45$ & 9.36 \\
9 & 50 & 1.10 & 6 & $40-45$ & 6.90 \\
\hline
\end{tabular}

Table 8. Effect of thickness on the drying time.

\begin{tabular}{cccccc}
\hline Exp. Run & $\begin{array}{c}\text { Temperature } \\
\left({ }^{\circ} \mathbf{C}\right)\end{array}$ & $\begin{array}{c}\text { Air Velocity } \\
\mathbf{m} / \mathbf{s}\end{array}$ & $\begin{array}{c}\text { Thickness } \\
\mathbf{( m m})\end{array}$ & $\begin{array}{c}\text { Relative } \\
\text { Humidity } \mathbf{( \% )}\end{array}$ & $\begin{array}{c}\text { Drying } \\
\text { Time (h) }\end{array}$ \\
\hline 1 & 50 & 1.10 & 12 & $35-38$ & 14.57 \\
2 & 50 & 1.10 & 10 & $35-38$ & 11.23 \\
3 & 50 & 1.10 & 8 & $35-38$ & 9.40 \\
4 & 50 & 1.10 & 6 & $35-38$ & 6.40 \\
5 & 50 & 1.10 & 4 & $35-38$ & 5.23 \\
\hline
\end{tabular}

Table 9. Effect of air relative humidity on the drying time.

\begin{tabular}{cccccc}
\hline No. & $\begin{array}{c}\text { Temperature } \\
\left({ }^{\circ} \mathbf{C}\right)\end{array}$ & $\begin{array}{c}\text { Air Velocity } \\
\mathbf{m} / \mathbf{s}\end{array}$ & $\begin{array}{c}\text { Thickness } \\
\mathbf{( m m})\end{array}$ & $\begin{array}{c}\text { Relative } \\
\text { Humidity } \mathbf{( \% )}\end{array}$ & $\begin{array}{c}\text { Drying } \\
\text { Time (h) }\end{array}$ \\
\hline 1 & 50 & 1.10 & 6 & $40-45$ & 6.90 \\
2 & 50 & 1.10 & 6 & $35-38$ & 5.53 \\
3 & 50 & 1.10 & 6 & $25-28$ & 4.70 \\
\hline
\end{tabular}

By increasing the slice thickness from 4 to $12 \mathrm{~mm}$ at $50{ }^{\circ} \mathrm{C}$ and with an air velocity of $1.1 \mathrm{~m} / \mathrm{s}$, the drying time increased from 5.23 to $14.3 \mathrm{~h}$. A similar relation between drying time and slice thickness was found by [53]. Of course, the shortest drying time cannot be selected as the only objective function for process conditions optimization. The quality of the product, i.e., color, texture, taste etc., can be influenced by the process conditions [54]. However, optimal product water activity cannot only optimize the drying time but also many product quality parameters. 


\section{Conclusions}

In the present study, apple slices were experimentally and mathematically studied under various conditions such as temperature, air flow rates, ambient air relative humidity, and slice thickness. The samples were dried from an initial moisture content of $86.7 \%$ to a moisture content of $20 \%$ (w.b), corresponding to product water activity of $0.45 \pm 0.05$. During the experiment, up to $96 \%$ of the total water content of apples was evaporated. By increasing the temperature in the drying chamber from 40 to $50^{\circ} \mathrm{C}$, at an air velocity of $1.1 \mathrm{~m} / \mathrm{s}$, the drying time decreased by about $300 \mathrm{~min}$. By increasing the air velocity from 0.60 to $0.85 \mathrm{~m} / \mathrm{s}$, the drying time increased by about $100 \mathrm{~min}$. The influence of the sample thickness was the most significant; by increasing the slice thickness from 4 to $12 \mathrm{~mm}$, the time required to achieve $20 \%$ moisture content increased by more than $500 \mathrm{~min}$. The effective diffusion coefficient of water in apple slices varied between $1.9 \times 10^{-10}$ and $7.0 \times 10^{-10} \mathrm{~m}^{2} / \mathrm{s}$. During the initial drying phase when free water is evaporated, the water activity of the samples remains practically constant. After evaporation of free water, the water activity of the products rapidly decreases. At high drying rates, a small change in the drying time can significantly influence the value of the product's water activity. A thin-layer model represented by a single equation valid for all process conditions described all 3780 experimental points with $R^{2}=0.9775, X^{2}=0.002001$ and MRSE $=0.04471$.

Author Contributions: Conceptualization, M.J.R. and J.H.; methodology, M.J.R.; software, M.J.R.; validation, M.J.R., and A.W.N.; formal analysis, A.W.N.; investigation, M.J.R.; resources, J.H.; data curation, M.J.R.; writing—original draft preparation, M.J.R.; writing_review and editing, M.J.R. and J.H.; visualization, M.J.R. and A.W.N.; supervision, J.H.; project administration, J.H.; funding acquisition, J.H. All authors have read and agreed to the published version of the manuscript.

Funding: This work was supported by project APVV-15-0148 provided by the Slovak Research and Development Agency and it was realized thanks to the support of the SlovakAid projects SAMRS/AFG/2016/01/04 and SAMRS/AFG/2019/01/01.

Acknowledgments: The authors would like to thank the Kabul Polytechnic University, Faculty of Chemical Technology, Department of Food Technology for creating a suitable environment for this research to be realized.

Conflicts of Interest: The authors declare no conflict of interest. The funders had no role in the design of the study; in the collection, analyses, or interpretation of data; in the writing of the manuscript, or in the decision to publish the results.

\section{References}

1. Pasban, A.; Sadrnia, H.; Mohebbi, M.; Shahidi, S.A. Spectral method for simulating 3D heat and mass transfer during drying of apple slices. J. Food Eng. 2017, 212, 201-212. [CrossRef]

2. Tomic, N.; Djekic, I.; Zambon, A.; Spilimbergo, S.; Bourdoux, S.; Holtze, E.; Hofland, G.; Sut, S.; Dall'Acqua, S.; Smigic, N.; et al. Challenging chemical and quality changes of supercritical $\mathrm{CO}_{2}$ dried apple during long-term storage. LWT 2019, 110, 132-141. [CrossRef]

3. Akharume, F.; Singh, K.; Jaczynski, J.; Sivanandan, L. Microbial shelf stability assessment of osmotically dehydrated smoky apples. LWT 2018, 90, 61-69. [CrossRef]

4. Timoumi, S.; Mihoubi, D.; Zagrouba, F. Shrinkage, vitamin C degradation and aroma losses during infra-red drying of apple slices. LWT Food Sci. Technol. 2007, 40, 1648-1654. [CrossRef]

5. Noori, A.W.; Royen, M.J.; Haydary, J. An active indirect solar system for food products drying. Acta Chim. Slovaca 2019, 12, 142-149. [CrossRef]

6. Winiczenko, R.; Górnicki, K.; Kaleta, A.; Martynenko, A.; Janaszek-Mańkowska, M.; Trajer, J. Multi-objective optimization of convective drying of apple cubes. Comput. Electron. Agric. 2018, 145, 341-348. [CrossRef]

7. Kwok, B.H.L.; Hu, C.; Durance, T.; Kitts, D.D. Dehydration techniques affect phytochemical contents and free radical scavenging activities of Saskatoon berries (Amelanchier alnifolia Nutt.). J. Food Sci. 2004, 69, SNQ122-SNQ126. [CrossRef]

8. Wojdylo, A.; Figiel, A.; Oszmianski, J. Influence of temperature and time of apple drying on phenolic compounds content and their antioxidant activity. Pol. J. Food Nutr. Sci. 2007, 57, 601-605.

9. Paunović, D.M.; Zlatković, B.P.; Mirković, D.D. Kinetics of drying and quality of the apple cultivars Granny Smith, Idared and Jonagold. J. Agric. Sci. Belgrade 2010, 55, 261-272. [CrossRef] 
10. Li, X.; Wu, X.; Bi, J.; Liu, X.; Li, X.; Guo, C. Polyphenols accumulation effects on surface color variation in apple slices hot air drying process. LWT 2019, 108, 421-428. [CrossRef]

11. Antal, T.; Kerekes, B.; Sikolya, L.; Tarek, M. Quality and Drying Characteristics of Apple Cubes Subjected to Combined Drying (FD Pre-Drying and HAD Finish-Drying). J. Food Process. Preserv. 2015, 39, 994-1005. [CrossRef]

12. Polat, A.; Taskin, O.; Izli, N.; Asik, B.B. Continuous and intermittent microwave-vacuum drying of apple: Drying kinetics, protein, mineral content, and color. J. Food Process Eng. 2019, 42, e13012. [CrossRef]

13. Lewicki, P.P.; Jakubczyk, E. Effect of hot air temperature on mechanical properties of dried apples. J. Food Eng. 2004, 64, 307-314. [CrossRef]

14. Toğrul, H. Simple modeling of infrared drying of fresh apple slices. J. Food Eng. 2005, 71, 311-323. [CrossRef]

15. Wang, J.; Chao, Y. Drying characteristics of irradiated apple slices. J. Food Eng. 2002, 52, 83-88. [CrossRef]

16. Velić, D.; Planinić, M.; Tomas, S.; Bilić, M. Influence of airflow velocity on kinetics of convection apple drying. J. Food Eng. 2004, 64, 97-102. [CrossRef]

17. Vega-Gálvez, A.; Ah-Hen, K.; Chacana, M.; Vergara, J.; Martínez-Monzó, J.; García-Segovia, P.; Lemus-Mondaca, R.; Di Scala, K. Effect of temperature and air velocity on drying kinetics, antioxidant capacity, total phenolic content, colour, texture and microstructure of apple (var. Granny Smith) slices. Food Chem. 2012, 132, 51-59. [CrossRef]

18. Nadian, M.H.; Rafiee, S.; Aghbashlo, M.; Hosseinpour, S.; Mohtasebi, S.S. Continuous real-time monitoring and neural network modeling of apple slices color changes during hot air drying. Food Bioprod. Process. 2015, 94, 263-274. [CrossRef]

19. Celma, A.R.; Cuadros, F.; López-Rodríguez, F. Characterisation of industrial tomato by-products from infrared drying process. Food Bioprod. Process. 2009, 87, 282-291. [CrossRef]

20. Aktaş, M.; Ceylan, İ.; Yilmaz, S. Determination of drying characteristics of apples in a heat pump and solar dryer. Desalination 2009, 239, 266-275. [CrossRef]

21. Oforkansi, B.C.; Oduola, M.K. Mathematical model of thin-layer drying process in a plantain sample. Int. J. Eng. Res. 2016, 5, 364-366.

22. Silva, F.P.D.; Siqueira, V.C.; Quinzani, G.A.; Martins, E.A.; Goneli, A.L. Drying kinetics of niger seeds. Eng. Agrícola 2017, 37, 727-738. [CrossRef]

23. Seiiedlou, S.; Ghasemzadeh, H.R.; Hamdami, N.; Talati, F.; Moghaddam, M. Convective drying of apple: Mathematical modeling and determination of some quality parameters. Int. J. Agric. Biol. 2010, 12, 171-178.

24. Akpinar, E.K. Drying of mint leaves in a solar dryer and under open sun: Modelling, performance analyses. Energy Convers. Manag. 2010, 51, 2407-2418. [CrossRef]

25. Ando, Y.; Hagiwara, S.; Nabetani, H.; Sotome, I.; Okunishi, T.; Okadome, H.; Orikasa, T.; Tagawa, A. Effects of prefreezing on the drying characteristics, structural formation and mechanical properties of microwave-vacuum dried apple. J. Food Eng. 2019, 244, 170-177. [CrossRef]

26. Royen, M.J.; Noori, A.W.; Haydary, J. Batch drying of sliced tomatoes at specific ambient conditions. Acta Chim. Slovaca 2018, 11, 134-140. [CrossRef]

27. Shahari, N.A. Mathematical Modelling of Drying Food Products: Application to Tropical Fruits. Ph.D. Thesis, University of Nottingham, Nottingham, UK, 2012.

28. Younis, M.; Abdelkarim, D.; El-Abdein, A.Z. Kinetics and mathematical modeling of infrared thin-layer drying of garlic slices. Saudi J. Biol. Sci. 2018, 25, 332-338. [CrossRef]

29. Mariem, S.B.; Mabrouk, S.B.; Khan, M. Drying characteristics of tomato slices and mathematical modeling. Int. J. Energy Eng. 2014, 4, 17-24.

30. Akpinar, E.K.; Bicer, Y. Mathematical modelling of thin layer drying process of long green pepper in solar dryer and under open sun. Energy Convers. Manag. 2008, 49, 1367-1375. [CrossRef]

31. Sacilik, K.; Keskin, R.; Elicin, A.K. Mathematical modelling of solar tunnel drying of thin layer organic tomato. J. Food Eng. 2006, 73, 231-238. [CrossRef]

32. Doymaz, İ. Effect of citric acid and blanching pre-treatments on drying and rehydration of Amasya red apples. Food Bioprod. Process. 2010, 88, 124-132. [CrossRef]

33. Chen, Q.; Bi, J.; Wu, X.; Yi, J.; Zhou, L.; Zhou, Y. Drying kinetics and quality attributes of jujube (Zizyphus jujuba Miller) slices dried by hot-air and short-and medium-wave infrared radiation. LWT Food Sci. Technol. 2015, 64, 759-766. [CrossRef] 
34. Kaleta, A.; Górnicki, K.; Winiczenko, R.; Chojnacka, A. Evaluation of drying models of apple (var. Ligol) dried in a fluidized bed dryer. Energy Convers. Manag. 2013, 67, 179-185. [CrossRef]

35. Lertworasirikul, S. Drying kinetics of semi-finished cassava crackers: A comparative study. LWT Food Sci. Technol. 2008, 41, 1360-1371. [CrossRef]

36. Lahsasni, S.; Kouhila, M.; Mahrouz, M.; Jaouhari, J.T. Drying kinetics of prickly pear fruit (Opuntia ficus indica). J. Food Eng. 2004, 61, 173-179. [CrossRef]

37. Atalay, H.; Coban, M.T.; Kıncay, O. Modeling of the drying process of apple slices: Application with a solar dryer and the thermal energy storage system. Energy 2017, 134, 382-391. [CrossRef]

38. Wang, Z.; Sun, J.; Liao, X.; Chen, F.; Zhao, G.; Wu, J.; Hu, X. Mathematical modeling on hot air drying of thin layer apple pomace. Food Res. Int. 2007, 40, 39-46. [CrossRef]

39. Babetto, A.C.; Freire, F.B.; Barrozo, M.A.S.; Freire, J.T. Drying of garlic slices: Kinetics and nonlinearity measures for selecting the best equilibrium moisture content equation. J. Food Eng. 2011, 107, 347-352. [CrossRef]

40. Menlik, T.; Özdemir, M.B.; Kirmaci, V. Determination of freeze-drying behaviors of apples by artificial neural network. Expert Syst. Appl. 2010, 37, 7669-7677. [CrossRef]

41. Assis, F.R.; Rodrigues, L.G.G.; Tribuzi, G.; de Souza, P.G.; Carciofi, B.A.M.; Laurindo, J.B. Fortified apple (Malus spp., var. Fuji) snacks by vacuum impregnation of calcium lactate and convective drying. LWT 2019, 113, 108298. [CrossRef]

42. Haydary, J.; Steltenpohl, P. Chemical Engineering II, 1st ed.; Ministry of higher education of Afghanistan: Kabul, Afghanistan, 2015.

43. Corzo, O.; Bracho, N.; Alvarez, C. Water effective diffusion coefficient of mango slices at different maturity stages during air drying. J. Food Eng. 2008, 87, 479-484. [CrossRef]

44. Fernando, W.J.N.; Low, H.C.; Ahmad, A.L. Dependence of the effective diffusion coefficient of moisture with thickness and temperature in convective drying of sliced materials. A study on slices of banana, cassava and pumpkin. J. Food Eng. 2011, 102, 310-316. [CrossRef]

45. Kaya, A.; Aydın, O.; Demirtaş, C. Drying kinetics of red delicious apple. Biosyst. Eng. 2007, 96, 517-524. [CrossRef]

46. Gómez-Daza, J.C.; Ochoa-Martínez, C.I. Kinetic aspects of a dried thin layer carrot in a heat pump dryer. Dyna 2016, 83, 16-20. [CrossRef]

47. Mohamed, L.A.; Kane, C.E.; Kouhila, M.; Jamali, A.; Mahrouz, M.; Kechaou, N. Thin layer modelling of Gelidium sesquipedale solar drying process. Energy Convers. Manag. 2008, 49, 940-946. [CrossRef]

48. Akoy, E.O.M. Experimental characterization and modeling of thin-layer drying of mango slices. Int. Food Res. J. 2014, 21, 1911-1917.

49. Doymaz, I. Air-drying characteristics of tomatoes. J. Food Eng. 2007, 78, 1291-1297. [CrossRef]

50. Sacilik, K.; Elicin, A.K. The thin layer drying characteristics of organic apple slices. J. Food Eng. 2006, 73, 281-289. [CrossRef]

51. Schössler, K.; Jäger, H.; Knorr, D. Effect of continuous and intermittent ultrasound on drying time and effective diffusivity during convective drying of apple and red bell pepper. J. Food Eng. 2012, 108, 103-110. [CrossRef]

52. Zeuthen, P.; Bøgh-Sørensen, L. (Eds.) Food Preservation Techniques; Woodhead Publishing Limited: Cambridge, UK, 2003.

53. Akpinar, E.K.; Bicer, Y.; Midilli, A.D.N.A.N. Modeling and experimental study on drying of apple slices in a convective cyclone dryer. J. Food Process Eng. 2003, 26, 515-541. [CrossRef]

54. Nowak, D.; Lewicki, P.P. Quality of infrared dried apple slices. Dry. Technol. 2005, 23, 831-846. [CrossRef]

Publisher's Note: MDPI stays neutral with regard to jurisdictional claims in published maps and institutional affiliations. 